\title{
Osteogenesis of MC3T3 Preosteoblasts on 3D Bioactive Peptide Modified Nano-Macroporous Bioactive Glass Scaffolds
}

\author{
Colin Przybylowski ${ }^{1,2}$, Mohamed Ammar ${ }^{3}$, Courtney LeBlon", Sabrina S. Jedlicka ${ }^{2,3,5 *}$ \\ ${ }^{1}$ Integrated Degree in Engineering, Arts \& Sciences (IDEAS) Program, Lehigh University, Bethlehem, PA, USA \\ ${ }^{2}$ Bioengineering Program, Lehigh University, Bethlehem, PA, USA \\ ${ }^{3}$ Department of Materials Science \& Engineering, Lehigh University, Bethlehem, PA, USA \\ ${ }^{4}$ Department of Mechanical Engineering \& Mechanics, Lehigh University, Bethlehem, PA, USA \\ ${ }^{5}$ Center for Advanced Materials \& Nanotechnology, Lehigh University, Bethlehem, PA, USA \\ Email: ssj207@lehigh.edu
}

Received 13 March 2015; accepted 30 June 2015; published 3 July 2015

Copyright (C) 2015 by authors and Scientific Research Publishing Inc.

This work is licensed under the Creative Commons Attribution International License (CC BY).

http://creativecommons.org/licenses/by/4.0/

cC) (7) Open Access

\begin{abstract}
Biointerface design that targets osteogenesis is a growing area of research with significant implications in biomedicine. Materials known to either support or stimulate osteogenesis are composed of a biomimetic ceramic material, such as bioactive glass. Bioactive glass is osteoproductive, and the potential for osteoproductivity can be enhanced by the addition of proteins or other additives designed to alter functionality. In addition, soluble growth factors are often added to osteogenic culture on bioactive glasses, further intensifying the effects of the material. In this paper, synthetic peptide combinations, covalently bound to a three-dimensional bioactive glass network, are used to mimic the effects of the whole fibronectin and bone morphogenetic proteins (BMP) 2 and 9. Peptide-silanes possessing critical binding sequences from each of these proteins are synthesized and used to decorate the surface of three-dimensional (3D) nano-macroporous bioactive glass. MC3T3 preosteoblast cells are then assessed for differentiation on the materials in the absence of soluble differentiation cues. MC3T3 preosteoblasts undergo enhanced differentiation on the peptide-silane samples over the standard nano-macroporous bioactive glass, and the differentiation capacity of the cells exposes only to peptide-silane surfaces approaches that of cells grown in chemical differentiation induction media.
\end{abstract}

\section{Keywords}

Bioactive Glass, Bioactive Peptide, MC3T3, Osteogenesis

\footnotetext{
${ }^{*}$ Corresponding author.
}

How to cite this paper: Przybylowski, C., Ammar, M., LeBlon, C. and Jedlicka, S.S. (2015) Osteogenesis of MC3T3 Preosteoblastson 3D Bioactive Peptide Modified Nano-Macroporous Bioactive Glass Scaffolds. Journal of Biomaterials and Nanobiotechnology, 6, 146-159. http://dx.doi.org/10.4236/ibnb.2015.63015 


\section{Introduction}

Biomaterials designed for bone repair benefit from an interface that is designed to increase osteogenesis. Bioactive glasses have been shown to be osteoproductive, stimulating osteogenesis via surface and solution-mediated mechanisms [1]-[3]. Therefore, bioactive glasses have received considerable attention from researchers aiming to enhance the treatment of bony defects in orthopedics and dentistry [1] [4]-[12]. Perhaps the most useful characteristic of bioactive glasses is the rapid surface reaction rate [13]-[18]. This rapid reaction rate leads to direct bone attachment. Bioactive glasses are quite flexible with regards to manufacturing, and also are amenable to surface modification, opening up a wide array of potential formats and compositions that offer versatility and unique properties [5]-[8] [19]-[23].

Osteogenic cells exhibit enhanced growth and biological activity in the presence of 45S5 bioactive glass substrates [3] [5] [9] [14] [24]-[33]. Studies performed in vivo have shown that bioactive glasses lead to enhanced proliferation and differentiation of progenitor cells [1] [25] [28] [29] [32]. This enhancement of osteogenic behavior has been linked to an enhanced production of biological growth factors and other proteins implicated in cell proliferation and tissue organization [3] [13] [24] [34].

One common research goal for bioactive glass as a clinical treatment for bone defects is to increase the tissue engineering potential. Several potential improvements have been suggested, including surface modification with bioactive proteins [23] [35] [36] and incorporation of growth factors [4] [5] [36] into the materials for slow release into the extracellular surroundings. While these approaches are promising, controlling the conformation of proteins that contact the highly reactive surface is challenging. Therefore, many researchers have chosen to use highly specific synthetic peptides that mimic protein motifs, such as the RGD group from Fibronectin Type III repeats [37]-[39]. This study examines the potential of mixed peptide motifs on three-dimensional, nano-macroporous bioactive glass scaffolds. Specifically, peptides derived from growth factors that are implicated in osteogenesis were chosen. The peptides were incorporated through an established peptide-silane technique, via covalent modification of the N-terminus with an alkoxysilane moiety. The peptides chosen were the RGD group to enhance cell adhesion [37] [38] [40]-[43], and sequence motifs from BMP-2 and BMP-9, for their potency to induce osteogenic differentiation [5] [44]-[48]. These peptides were covalently linked to a bioactive glass network using silane chemistry [49], and MC3T3 cells were used to examine the influence of bioactive peptides on the induction of osteogenesis on 3D bioactive glass monoliths.

\section{Materials and Methods}

\subsection{Cell Culture}

MC3T3-E1 cells (ATCC CRL-2593) (MC3T3) were maintained in Modifed Eagle’s Medium (alpha modification) $(\alpha-\mathrm{MEM})+7.5 \%$ bovine calf serum (BCS) $+2.5 \%$ fetal bovine serum (FBS) in a $5 \% \mathrm{CO}_{2}, 37^{\circ} \mathrm{C}$ humidified atmosphere. Media was replaced three times a week and cells were split 1:50 when reaching 80\% confluency.

\subsection{Peptide-Silane Synthesis}

Three peptide-silanes were synthesized (Table 1), including AYAVTGRGDSPAS (RGD), ACGGKVGKACCVPTKLSPISVLYK (CGG), and ACKIPKASSVPTELSAISTLYL (CKI). Peptides were synthesized using solid-phase synthesis in an automated peptide synthesizer (ResPep, Intavis, Germany) using 9-fluorenylmethyloxycarbonyl (Fmoc) chemistry. Peptides were then conjugated with 3'-aminopropyl trimethoxysilane (APTMS) using carbonyldiimadazole (CDI) as a linker. Resulting peptide-silanes were cleaved using a cleavage cocktail consisting of $89 \%$ trifluoracetic acid, $5 \%$ phenol, $5 \%$ dd $\mathrm{H}_{2} \mathrm{O}$, and $1 \%$ triisopropylsilane. Peptides were then

Table 1. Peptide-silanes used in this study.

\begin{tabular}{ccc}
\hline Name & Sequence & Origin \\
\hline RGD & AYAVTGRGDSPASA [37]-[39] [43] & Fibronectin Type III $10_{10}$ \\
CGG & A $\underline{\text { GGGKVGKACCVPTKLSPISVLYKA [5] }}$ & BMP-9 \\
CKI & A $\underline{\text { CKIPKASSVPTELSAISTLYLA [48] }}$ & BMP-2 \\
\hline
\end{tabular}


ether precipitated and purified. Peptide conjugation is routinely confirmed using matrix assisted laser desorption ionization - mass spectrometry (MALDI-MS), with $\alpha$-cyano-4-hydroxycinnamic acid as the matrix [50].

\subsection{Material Preparation}

Bimodal (nano-macroporous) 3D bioactive glass scaffolds $\left(70 \% \mathrm{SiO}_{2}-30 \% \mathrm{CaO}\right)$ were synthesized as previously described [17] [51]-[53]. This process is summarized in Figure 1. Briefly, water soluble polymer polyethylene oxide (PEO, $\mathrm{Mw}=100,000,2.1 \mathrm{~g}$ ), was dissolved in $0.05 \mathrm{~N}$ acetic acid $\left(\mathrm{CH}_{3} \mathrm{COOH}, 30 \mathrm{~mL}\right)$. The mixture was stirred for 20 minutes to dissolve the polymer. Urea (1.35 g) and tetramethoxysilane (TMOS) (AcrosInorganics, $13.5 \mathrm{~mL}$ ) were added and vigorously stirred for 20 minutes. Calcium nitrate tetrahydrate $(9.27 \mathrm{~g})$ was then added and the mixture stirred for 10 more minutes. To accelerate gelation, aqueous hydrofluoric acid (HF, $6 \%$ ) was added. The sol was then cast into molds (which were sized to fit a 24 well tissue culture plate) and left to gel at $40^{\circ} \mathrm{C}$ for 24 hours. The resulting gel was dried at $60^{\circ} \mathrm{C}$ for 1 day (at a relative humidity of $90 \%$ ), followed by $180^{\circ} \mathrm{C}$ for 2 days. Following the drying, the gels were heat treated sequentially at $600^{\circ} \mathrm{C}$ for one hour and $700^{\circ} \mathrm{C}$ for two hours, with heating and cooling (to room temperature) rates of $100^{\circ} \mathrm{C} / \mathrm{h}$. The resulting scaffolds are shown in Figure 1.

Following synthesis, the scaffolds were prepared for cell culture. The scaffolds were autoclaved $\left(121^{\circ} \mathrm{C}, 15\right.$ minutes) and then submerged in Simulated Body Fluid (SBF) overnight (SBF: $138 \mu \mathrm{M} \mathrm{NaCl}, 4 \mu \mathrm{M} \mathrm{NaHCO}, 3$ $\mu \mathrm{M} \mathrm{KCl}, 1.4 \mu \mathrm{M} \mathrm{K}_{2} \mathrm{HPO}_{4}, 1.5 \mu \mathrm{M} \mathrm{MgCl}_{2}, 2.64 \mu \mathrm{M} \mathrm{CaCl}_{2}, 507 \mathrm{nM} \mathrm{Na}_{2} \mathrm{SO}_{4}$, and $50.56 \mu \mathrm{M}$ Tris, adjusted to $\mathrm{pH}$ 7.4 with $20 \mathrm{~mL}$ of $1.0 \mathrm{M} \mathrm{HCl}$ ). The peptide-silanes were dissolved in $50 \mu \mathrm{L}$ of dimethylsulfoxide. The peptidesilanes were then suspended in SBF, and pipetted on top of the scaffolds at $0.01 \%$ mole peptide: 1 mole $\mathrm{SiO}_{2}$. The experimental samples included bioactive glass samples with no peptides; with RGD (0.01 mole\% total peptide-silane: 1 mole Si); with RGD and CGG (0.02 mole\% total peptide-silane: 1 mole Si); and with RGD, CGG and CKI (0.03 mole\% total peptide-silane: 1 mole Si). Cells grown on scaffolds in differentiation media represented a positive control. All scaffolds were submerged in media overnight before cell seeding.

\subsection{Peptide Tagging with Fluorescent Dye}

To ensure that peptides were diffusing into the scaffolds, the RGD peptide was labeled using an amine reactive fluorescent peptide-labeling reagent (Cy3 mono-reactive NHS ester). The labeling reagent was used as specified by the manufacturer (GE Healthcare, Princeton, NJ). Labeled peptides were separated from free dye by dialysis.

\subsection{X-Ray Photoelectron Spectroscopy (XPS)}

Jedlicka et al. have previously described the analysis of sol-gel silica surfaces modified with peptide-silanes [49]. XPS data were obtained by a Kratos Ultra DLD spectrometer using monochromatic AlKR radiation of 1486.58

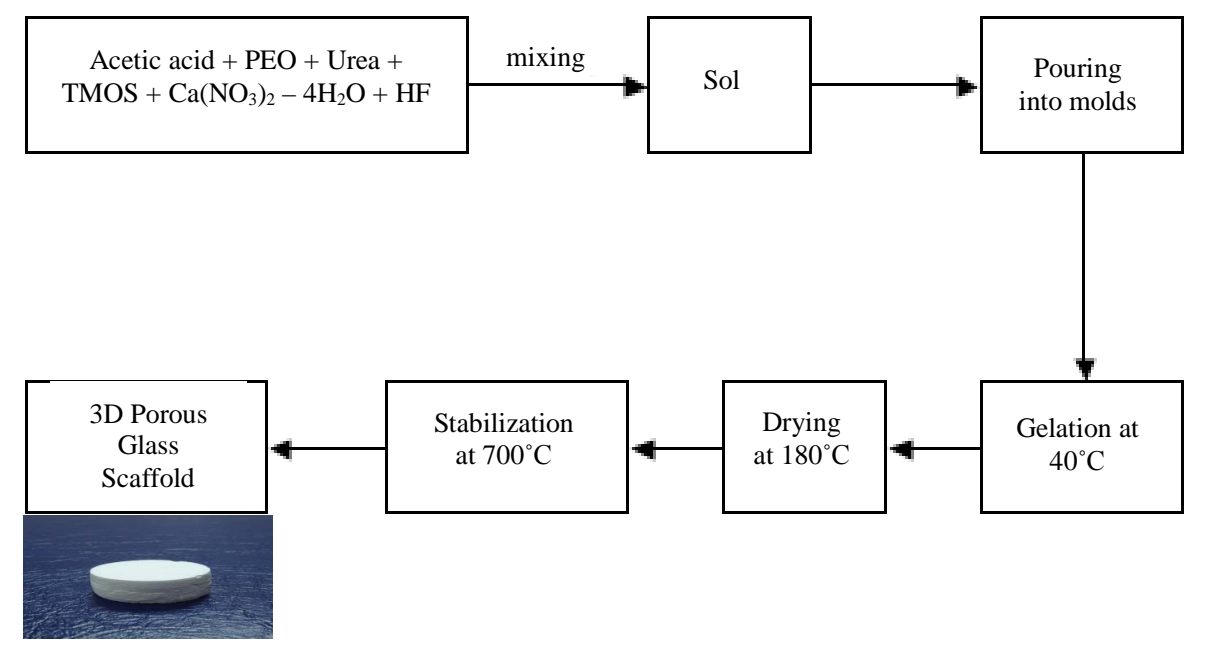

Figure 1. Three-dimensional nano-macroporous glass scaffold preparation. The scaffolds were made to fit in a 24 well tissue culture plate. 
$\mathrm{eV}$. The survey and high-resolution spectra were collected at a fixed analyzer pass energy of 160 and $20 \mathrm{eV}$, respectively. The spectra were collected at a $0^{\circ}$ and $60^{\circ}$ angle with respect to the surface normal. The atomic concentrations of the chemical elements in the near-surface region were estimated after the subtraction of a Shirleytype background, taking into account the corresponding Scofield atomic sensitivity factors and inelastic mean free pass (IMFP) of photoelectrons as a standard procedure of the CasaXPS software.

\subsection{Cell Culture on Materials}

MC3T3-E1 cells (ATCC CRL 2593), at passage numbers 7 - 9, were used to examine the osteogenic potential of the 3D peptide-modified scaffolds. MC3T3 cells were routinely maintained on tissue culture treated polystyrene (TCPS) dishes at $37^{\circ} \mathrm{C}$ in a humidified atmosphere containing 5\% CO2. Media was changed twice weekly. To seed cells on materials (Table 2), cells were removed from TCPS and seeded at a density of $1000 \mathrm{cells} / \mathrm{mm}^{3}$ onto sterilized scaffolds, via addition of a concentrated cell suspension in a drop-wise manner to ensure direct cell loading onto scaffolds. Samples were incubated at $37^{\circ} \mathrm{C}$ for $30 \mathrm{~min}$ to allow for cell attachment before new media was added to flood the samples. Cells were analyzed at variable time points (2, 3, 4, 5 weeks).

Table 2 summarizes the scaffolds/treatments examined in this study. The positive control (denoted Diff) was maintained on an unmodified 3D bioactive glass scaffold in differentiation media $(\alpha$-MEM $+7.5 \%$ BCS $+2.5 \%$ FBS $+0.01 \mathrm{~mol} / \mathrm{L} \beta$-glycerol phosphate $+50 \mu \mathrm{g} / \mathrm{mL}$ of L-ascorbic acid) throughout the experimental timeline. The experimental samples (RGD, CGG and CKI) were maintained in standard maintenance medium ( $\alpha$-MEM + $7.5 \%$ BCS $+2.5 \%$ FBS), to assess the potential of the peptides to induce differentiation on the 3D scaffolds in the absence of soluble differentiation cues. The negative control cells were grown in proliferation media on the 3D bioactive glass scaffolds (BIO). Triplicate samples were prepared for each successive experiment. Given the 3D nature of the scaffolds, daily cell monitoring was not possible; however, media color and clarity were checked on a regular basis to monitor for contamination.

\subsection{Cell Viability Assay}

Cell viability was assessed using a non-destructive Alamar Blue Assay, per manufacturer's instructions (Invitrogen). This assay was chosen over the MTT assay, due to a slightly higher sensitivity, and the non-destructive nature of the dyes [54]. Samples were removed from cell media and incubated for 14.5 hours in $10 \%$ Alamar Blue solution. This timing was empirically determined for the MC3T3 cells. Solution absorbance was read at $620 \mathrm{~nm}$ and $590 \mathrm{~nm}$, and the percentage of reduced Alamar Blue was determined. Cell counts were determined from this reduction through an experimentally derived standard curve.

\subsection{Quantitative Real-Time Polymerase Chain Reaction (qRT-PCR)}

RNA was extracted from the samples using the RNeasy Plus Micro Kit (Qiagen), per manufacturer's instructions, with slight modifications. Cell lysate was obtained by crushing the scaffolds while they were submerged in lysis buffer. This was followed by centrifugation. Initial RNA concentrations were very low, so the process was modified by then adding RNase-free water to the scaffold debris and mixing (to dissolve the RNA that had bound to the silica particles from the scaffold), centrifuging and adding this supernatant to the cell lysate. The last step of the protocol was modified to elute a total of $20 \mu \mathrm{l}$ of RNA by twice adding $12 \mu \mathrm{l}$ of RNase-free water to the spin column membrane and centrifuging.

qRT-PCR was performed using the Rotor-Gene ${ }^{\mathrm{TM}}$ SYBR Green RT-PCR Kit, with a Rotor-Gene qRT-PCR cycler. The genes of interest were glyceraldehyde 3 phosphate dehydrogenase (GAPDH) (control), Osteocalcin (BGLAP), Transcription factor RunX2 (RunX), Alkaline Phosphatase (AP) and SMAD family member 4

Table 2. Materials/Specimens examined.

\begin{tabular}{lll}
\hline \multicolumn{1}{c}{ Experimental Samples } & Positive Control & Negative Control \\
\hline Bioactive Glass + RGD (RGD) & Bioactive Glass Only & Bioactive Glass Only \\
Bioactive Glass + RGD + CGG (CGG) & + & + \\
Bioactive Glass + RGD + CGG + CKI (CKI) & Differentiation Media (Diff) & Regular Media (BIO) \\
\hline
\end{tabular}


(SMAD4) (Table 3). The primers used in this study are listed in Table 3. Analysis of the cycle data was assessed using the $\Delta \Delta \mathrm{Ct}$ method, with a threshold value of $20 \%$ above the background. Efficiency values were empirically derived from 3 plates of differentiated cells (grown in the same media as the positive control) for the purposes of this analysis. Fold changes were determined through Ct comparison to the negative control. All data was subject to normalization to a housekeeping gene (GAPDH) corresponding to each experimental condition and specimen. All data was then averaged and subject to ANOVA statistical analysis.

\subsection{Scanning Electron Microscopy (SEM)}

To examine cell attachment and scaffold morphology, scanning electron microscopy (SEM) in environmental mode was used. Scaffolds were washed three times in $0.1 \mathrm{M}$ phosphate buffer and fixed in $12 \%$ gluteraldehyde overnight. Following fixation, specimens were washed again with phosphate buffer and dehydrated with an ethanol gradient: [25\% (10 minutes), 50\% (10 minutes), 75\% (15 minutes), 95\% (15 minutes) and $100 \%$ (3 × 10 minutes)]. Samples were then covered in hexamethyldisilazane (HMDS) for 10 minutes before drying in a dessicator overnight. Specimens were imaged in a Philips XL30 ESEM, at 0.2 torr, with an accelerating voltage of $5 \mathrm{kV}$.

\section{Results and Discussion}

In this study, we used mixed peptide silanes from fibronectin, BMP-2 and BMP-9 grafted onto three-dimensional nano-macroporous bioactive glass to examine the potential of these short peptides to influence osteogenic differentiation. SEM was used to assess that the surface morphology after grafting of the peptides was not significantly altered. SEM imaging (Figure 2) revealed that the surface morphology of the scaffolds was not significantly altered with the addition of peptide-silanes to the surface.

Specimens were also imaged after SBF submersion, prior to cell seeding. A difference in the hydroxyapatite layer after SBF incubation was observed in the SEM studies in our experiment between the control samples and the peptide grafted samples (Figure 3). This can be attributed to the presence of negatively charged groups within some of the amino acids in the peptides chains, such as glutamic acid in the CKI peptide sequence and aspartic acid in the RGD peptide sequence [55]. These amino acids carry carboxyl groups with negative charges that act like a nucleation sites for the hydroxyapatite crystals through the binding of the dissolved calcium ions to them [56].

Diffusion of the peptides through the 3D scaffolds was tracked using fluorescent microscopy. To visualize the peptide-silanes, the RGD peptide-silane was conjugated using a Cy3 monoreactive NHS ester dye for this experiment only (Figure 4). The conjugated peptide-silane was added at 0.01 mole\%: 1 mole Si to the scaffold structure in the same manner used in cell culture studies. Using the z-stacking feature, several levels of the 3D scaffold were inspected for fluorescence signature, confirming that the depth of penetration exceeded the microscope objectives working depth $(800 \mu \mathrm{m})$. While the additional fluorescent dye may have led to altered interactions between the peptide-silane and the bioactive glass surface, the peptide-silanes appear to diffuse freely through the bioactive glass network.

To confirm our fluorescent peptide-silane diffusion study, XPS was performed on the bioactive glass surfaces both before and after peptide additions to the materials. These data are summarized in Table 4 . The unmodified

\begin{tabular}{|c|c|c|c|}
\hline Gene & Description & Primer & $\mathbf{T m}$ \\
\hline GAPDH & $\begin{array}{l}\text { Glyceraldehyde 3-phosphate dehydrogenase } \\
\text { (reference gene) }\end{array}$ & $\begin{array}{l}\text { Forward: 5’ TCGGTGTGAACGGATTTGG 3’ } \\
\text { Reverse: 5’ TCTCCACTTTGCCACTGCA 3’ }\end{array}$ & $\begin{array}{l}55.4 \mathrm{C} \\
57.1 \mathrm{C}\end{array}$ \\
\hline BGLAP & Osteocalcin & $\begin{array}{l}\text { Forward: 5’ CTGACAAAGCCTTCATGTCCAA 3’ } \\
\text { Reverse: 5’ GCCGGAGTCTGTTCACTACCTT 3’ }\end{array}$ & $\begin{array}{l}55.6 \mathrm{C} \\
58.7 \mathrm{C}\end{array}$ \\
\hline Runx & Transcription Factor RunX2 & $\begin{array}{l}\text { Forward: 5’ CTTCAAGGTTGTAGCCCTCGGA 3’ } \\
\text { Reverse: 5’ ATGACGGTAACCACAGTCCCA 3’' }\end{array}$ & $\begin{array}{l}58.8 \mathrm{C} \\
58.2 \mathrm{C}\end{array}$ \\
\hline AP & Alkaline Phosphatase & $\begin{array}{l}\text { Forward: 5’ AAGGATATCGACGTGATCATGG 3’ } \\
\text { Reverse: 5’ GGCCTTCTCATCCAGTTCGTA 3’' }\end{array}$ & $\begin{array}{l}54.3 \mathrm{C} \\
56.5 \mathrm{C}\end{array}$ \\
\hline SMAD4 & SMAD family member 4 & $\begin{array}{l}\text { Forward: 5' CACAAGTCAGCCGGCCAGTATT 3' } \\
\text { Reverse: 5' TTCCAGTCCAGGTGGTAGT 3' }\end{array}$ & $\begin{array}{l}59.8 \mathrm{C} \\
60.1 \mathrm{C}\end{array}$ \\
\hline
\end{tabular}



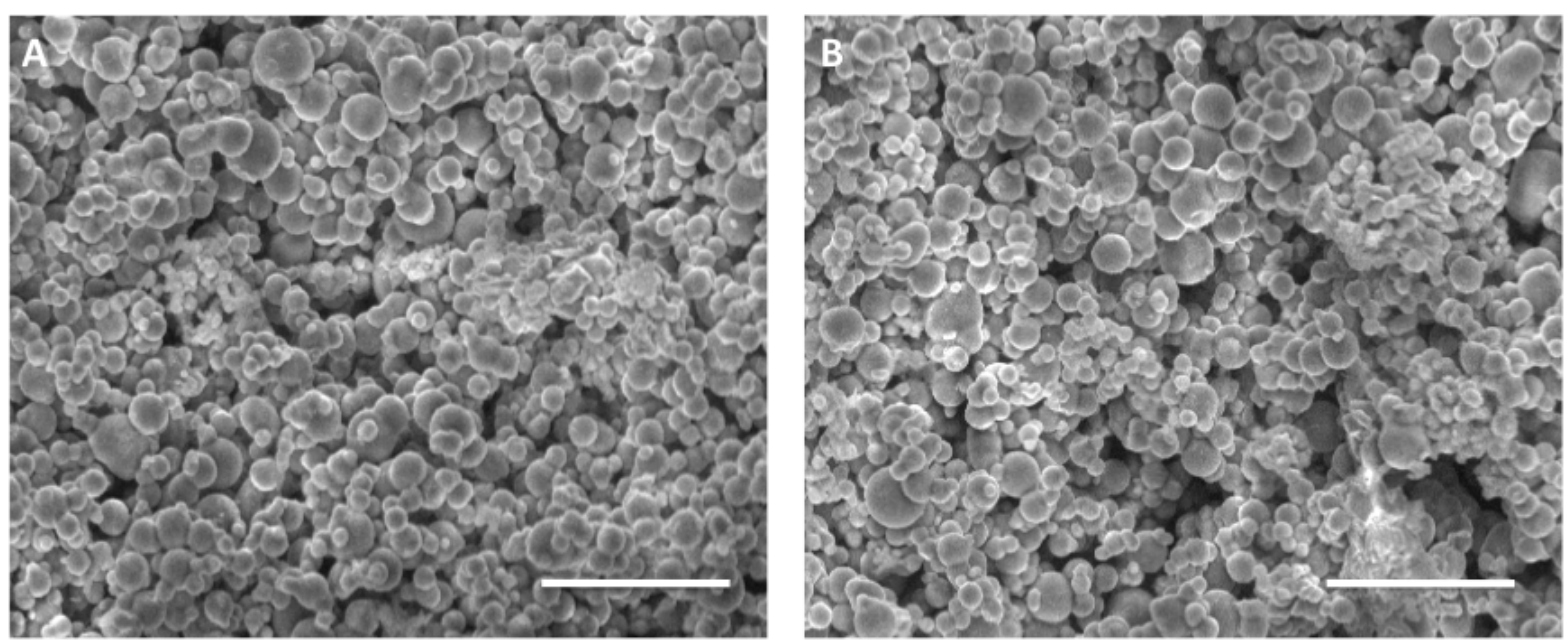

Figure 2. SEM image of nano-macroporous bioactive glass (A) before and (B) after covalent peptide modification with RGD, CGG and CKI peptide-silanes added at equal ratios for a total concentration of 0.03 mole\%: mole Si (CKI material). Scale bar $=50 \mu \mathrm{m}$.
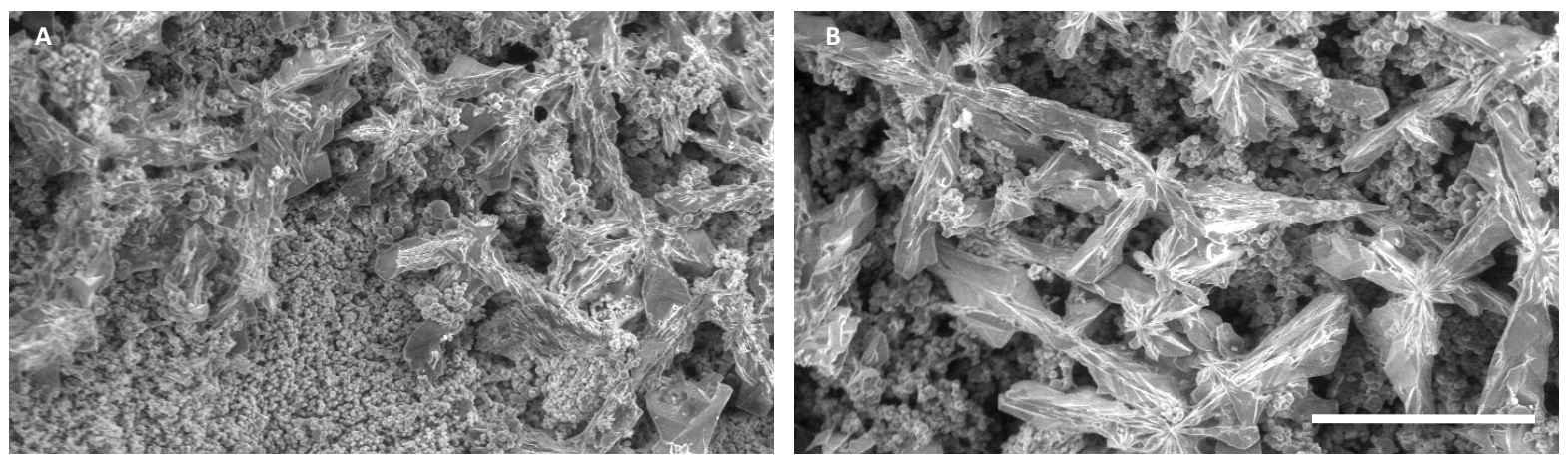

Figure 3. SEM image hydroxyapatite layer formation after SBF incubation on nano-macroporous bioactive glass (A) withouth and (B) with covalent peptide modifcation with RGD, CGG, and CKI added at equal ratios for a total concentration of 0.03 mole\%: mole \% Si (CKI material). Scale bar $=200 \mu \mathrm{m}$.
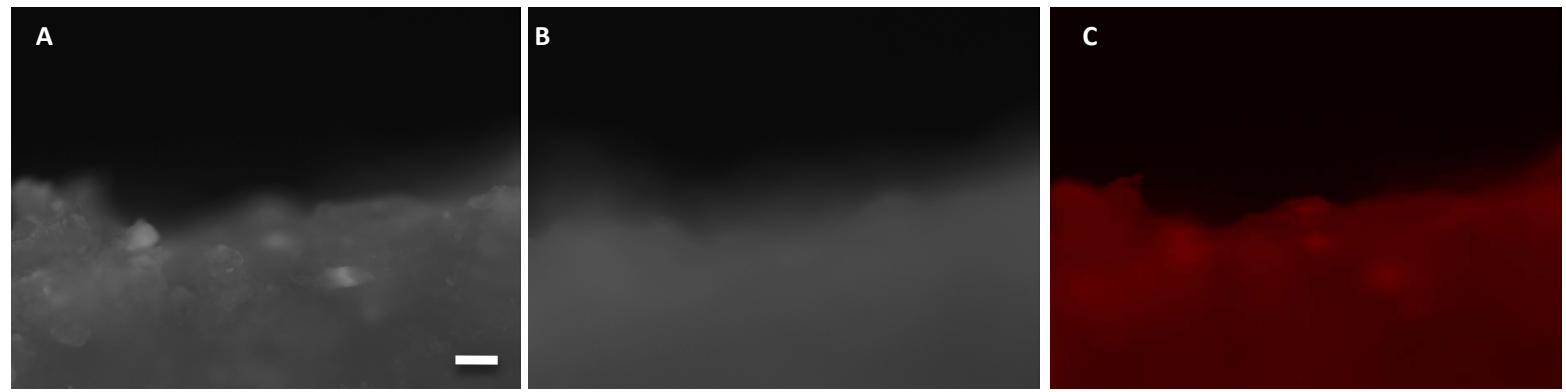

Figure 4. Fluorescent microscope image of fluorescent peptide modified nano-macroporous bioactive glass (A) at the surface, (B) $800 \mu \mathrm{m}$ into the surface and (C) z-stack image of 10 images between the surface and the upper working depth of the microscope objective of a scaffold modified with 0.01 mole \% fluorescent RGD peptide-silane: 1 mole Si. Scale bar $=50 \mu \mathrm{m}$.

bioactive glass, when analyzed with XPS, appears to possess a small degree of carbon contamination; therefore, the carbon percentages are not used to determine peptide-silane conjugation. The Nitrogen $1 \mathrm{~s}$ and Sulfur $2 \mathrm{p}$ are not seen on standard bioactive glass, however, as the peptide-silanes are added to the scaffolds, these elements begin to appear in the spectra. The RGD peptide-silane used in this study does not possess a cysteine residue, and no sulfur was detected on these specimens. However, as the CGG and CKI peptides are added, both of which possess a cysteine residue, $\mathrm{S} 2 \mathrm{p}$ is detected in the spectra, indicating that the peptide-silanes are present 
Table 4. XPS Analysis. BIO is unmodified three-dimensional nano-macroporous bioactive glass. RGD is BIO modified with 0.01 mole \% RGD peptide-silane: 1 mole of Si. CGG is RGD modified with an additional 0.01 mole \% CGG peptide-silane: 1 mole of Si (total of 0.02 mole \%: 1 mole of $\mathrm{Si}$ ). CKI is CGG modified with an additional 0.01 mole \% CKI peptide-silane: 1 mole of Si (total of 0.03 mole \%: 1 mole of $\mathrm{Si}$ ).

\begin{tabular}{cccccccccc}
\hline Sample & Location & Atomic $\%$ & & & & & \\
& & Ca 2p & O 1s & Si 2p & C 1s & N 1s & S 2p \\
BIO & Surface & 3.92 & 61.75 & 29.12 & 5.21 & 0 & N/D \\
BIO & Internal & 4.98 & 65.2 & 23.6 & 6.22 & 0 & N/D \\
RGD & Surface & 1.96 & 63.35 & 28.06 & 6.19 & 0.44 & N/D \\
RGD & Internal & 1.8 & 67.42 & 26.37 & 4.31 & 0.1 & N/D \\
CGG & Surface & 0.92 & 63.75 & 26.33 & 4.61 & 0.53 & 3.86 \\
CGG & Internal & 1.56 & 63.35 & 27.76 & 3.19 & 0.45 & 3.69 \\
CKI & Surface & 1.05 & 42.79 & 20.82 & 26.97 & 5.03 & 3.34 \\
CKI & Internal & 2.35 & 52.58 & 21.11 & 17.4 & 3.19 & 3.37 \\
\hline
\end{tabular}

on these specimens. In addition, the Nitrogen $1 \mathrm{~s}$ content also increases as a function of added peptide-silanes to the bioactive glass monoliths. Finally, the surface of the scaffolds experiences a 4 - 6 fold increase in C 1 s content when all three peptide-silanes are added collectively to the scaffolds. This could indicate some degree of peptide intermolecular association at the surface of the scaffolds, potentially preventing full diffusion of the three peptide-silanes throughout the inner structure of the monolith.

To augment the surface analysis and support the RGD fluorescence analysis, an internal XPS analysis on the peptide-silane modified specimens was performed. These are denoted as "Internal” in Table 4. To obtain these specimens, the original specimens were removed from the XPS and the top surface ( 1 mm) was scraped off with a sterile scalpel blade. The dust from the scraping was gently removed with air, and the specimens further analyzed. Of specific interest are the N 1 s and S 2p atomic percentages. Even after removal of $\sim 1 \mathrm{~mm}$ of the top surface of the bioactive glass, there remains nitrogen and sulfur in the XPS spectra, indicating diffusion and binding of the peptides within the bioactive glass inner structure. This is key in the modification, as the cells do infiltrate the scaffolds, and ideally, the peptides of interest would be present for the cells to bind to. This XPS data, combined with the fluorescent microscopy study, confirms that the peptide-silanes are distributed throughout the bulk of the scaffold, with the highest concentration at the surface, but with appreciable peptide-silane presentation throughout.

Following confirmation of successful conjugation, MC3T3 cells were seeded onto the materials and assessed for cell adhesion, cell proliferation and osteogenic differentiation. To examine cell morphology on the scaffolds and confirm cell adhesion on specimens, SEM analysis was performed. The SEM analysis confirmed that the cells adhered to all samples, and persisted at least three weeks into the experiment, when the images shown in Figure 5 were collected. The cells appear homogeneously distributed on the scaffolds, with cell extensions between the walls of the scaffolds. There are no significant morphological differences between the different specimens examined.

Proliferation analysis was performed using Alamar Blue (Figure 6). Alamar Blue is a non-destructive means to monitor cell growth using the reduction of Alamar Blue as an indicator of cell metabolism. All specimens allowed for significant cell adhesion, as demonstrated by the cell counts at Day 2. Within one week, the cell number had increased on all specimens, although not appreciably on the RGD and CKI materials. By Day 14, the cell number had declined, potentially indicating a degree of cell die-off as the cells filled the scaffold pores and began to undergo differentiation. Three weeks into the experiment, the cell numbers had increased again, which could be attributed to the overall size of the MC3T3 cells decreasing as cells undergo the early stages of differentiation. Finally, by Day 35, the cell number decreased again, possibly indicating a slowed degree of metabolism as calcification occurs. This apparent decrease in cell numbers was not accompanied by a reduction in the total mRNA isolated for qRT-PCR analysis, possibly indicating that the standard curve used in generating our cell numbers may not be applicable if the MC3T3 cells are reaching a late stage of differentiation. 

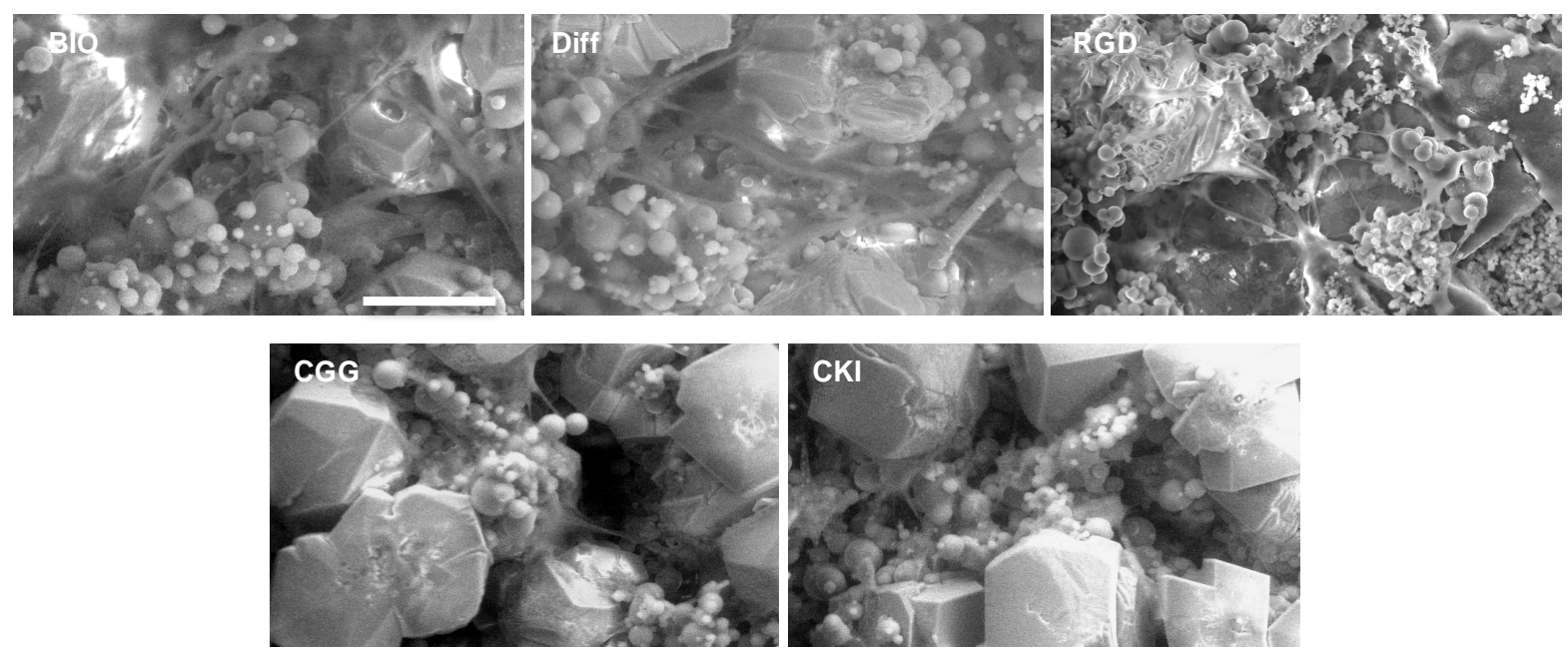

Figure 5. Environmental SEM images of MC3T3 cells adhered to the scaffolds three weeks after seeding. The specimen types are labeled on the images. Scale bar $=50 \mu \mathrm{m}$.

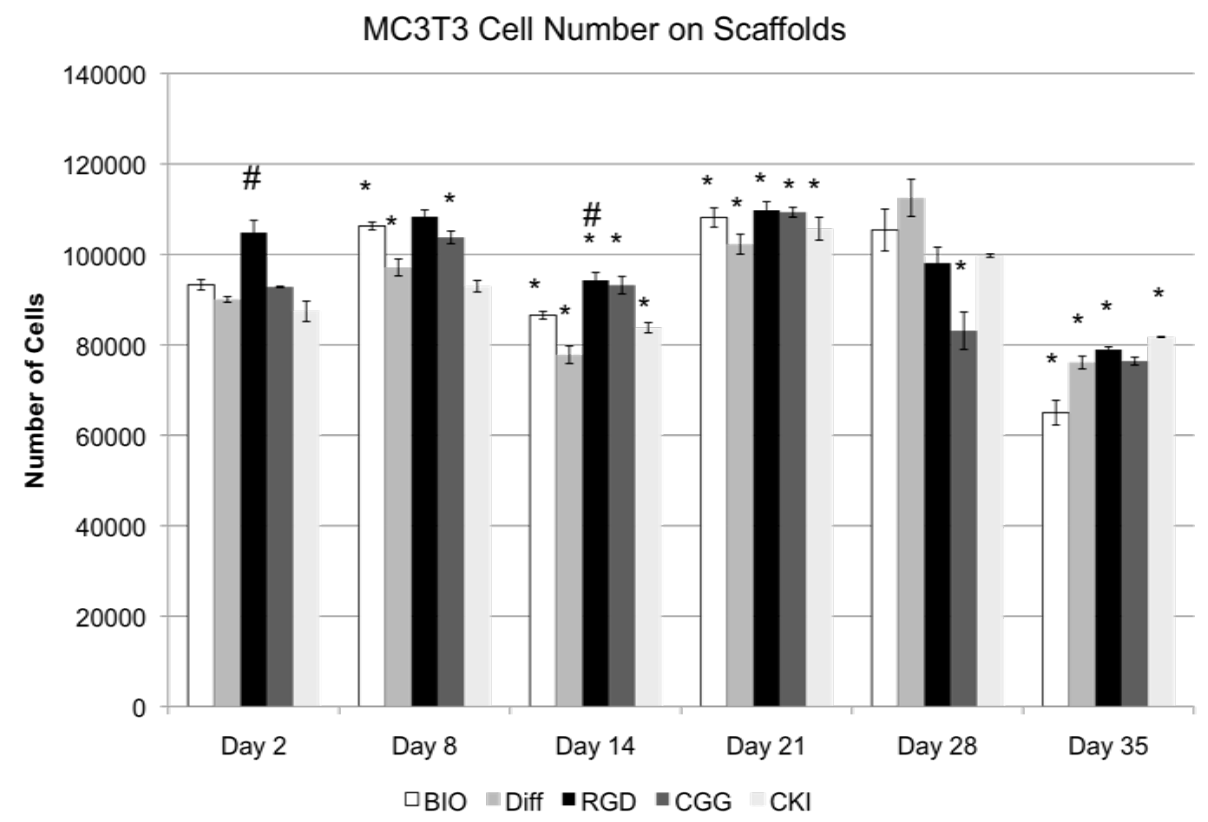

Figure 6. Cell counts on scaffolds using an Alamar Blue assay. Cells were treated with Alamar Blue for 14.5 hours starting at 48 hours after initial cell seeding. Cell counts were generated from an experimentally derived standard curve with undifferentiated cells. * = Significant Cell number change from previous timepoint examined, $\mathrm{p}<0.05$. \# = Significant cell number difference over Diff. at same time point, $\mathrm{p}<0.05$.

qRT-PCR was performed to assess the differentiation of the MC3T3 cells on the scaffolds on interest, in the absence of differentiation media. mRNA was extracted from the specimens at Days 21 and 35 (Weeks 3 and 5) after seeding. Genes analyzed included BGLAP (osteocalcin), AP (alkaline phosphatase), SMAD4, RunX, and GAPDH was used as a housekeeping gene. Osteocalcin is a late stage marker of osteogenesis implicated in bone mineralization [57]-[60]. The expression of this protein increases during osteogenesis, reaching a maximum concentration at four weeks during in vitro differentiation experiments. Alkaline phosphatase is an enzyme that plays a role in bone mineralization and is considered an early stage marker of osteogenesis [57]. SMAD4 and RunX were chosen due to their known involvement in osteogenesis of MC3T3 pre-osteoblast cells. Specifically, RunX is essential in regulating osteocalcin and osteopontin expression during osteogenesis and is considered to be the central control gene in osteogenesis [1] [30] [46] [57] [59] [61] [62]. Smad4 is a transcription factor in- 
volved in transforming growth factor- $\beta$ (TGF- $\beta$ ) signaling during bone growth and remodeling. It is also linked to osteocalcin expression via the activity of Smad2 [44] [63] [64]. qRT-PCR data was analyzed using the $\Delta \Delta \mathrm{Ct}$ method, using GAPDH as a control gene, and the mRNA from the cells grown on nano-macroporous bioactive glass in the absence of any differentiation media (BIO) as the reference specimens. The data is presented as the fold change over the BIO specimens in Figure 7.

BGLAP (osteocalcin) expression is significantly upregulated in the cells growing on unmodified bioactive glass treated with differentiation media by Week 3 . This upregulation persists through Week 5 . The RGD, CGG, and CKI specimens have a moderate, statistically significant increase in osteocalcin expression at Week 3 (compared to the BIO specimen) as well; however, the upregulation is not as apparent as in the cells treated with differentiation media (Diff). As bioactive glass is known to be osteoinductive by itself [2] [10] [12] [24], this increase in the late stage marker on the peptide-modified substrates without the addition of any additional osteoinductive compounds is considered significant. Future experiments, combining the peptide-silane modified surfaces and differentiation media will be performed to assess how these scaffolds would perform in a natural environment.

Alkaline phosphatase was not significantly upregulated over the BIO samples in any of the treatments at Week 3. AP mRNA has been shown to be upregulated in osteoblasts grown on bioactive glass, therefore, this result is not surprising [65] [66]. The CKI and CGG specimens both exhibit a jump in AP mRNA levels, potentially indicating the synthesis of fresh enzyme to augment bone growth. Typically AP mRNA expression will peak about 3 weeks into differentiation; however, there is an increase in AP activity by Week 5 of osteogenesis.

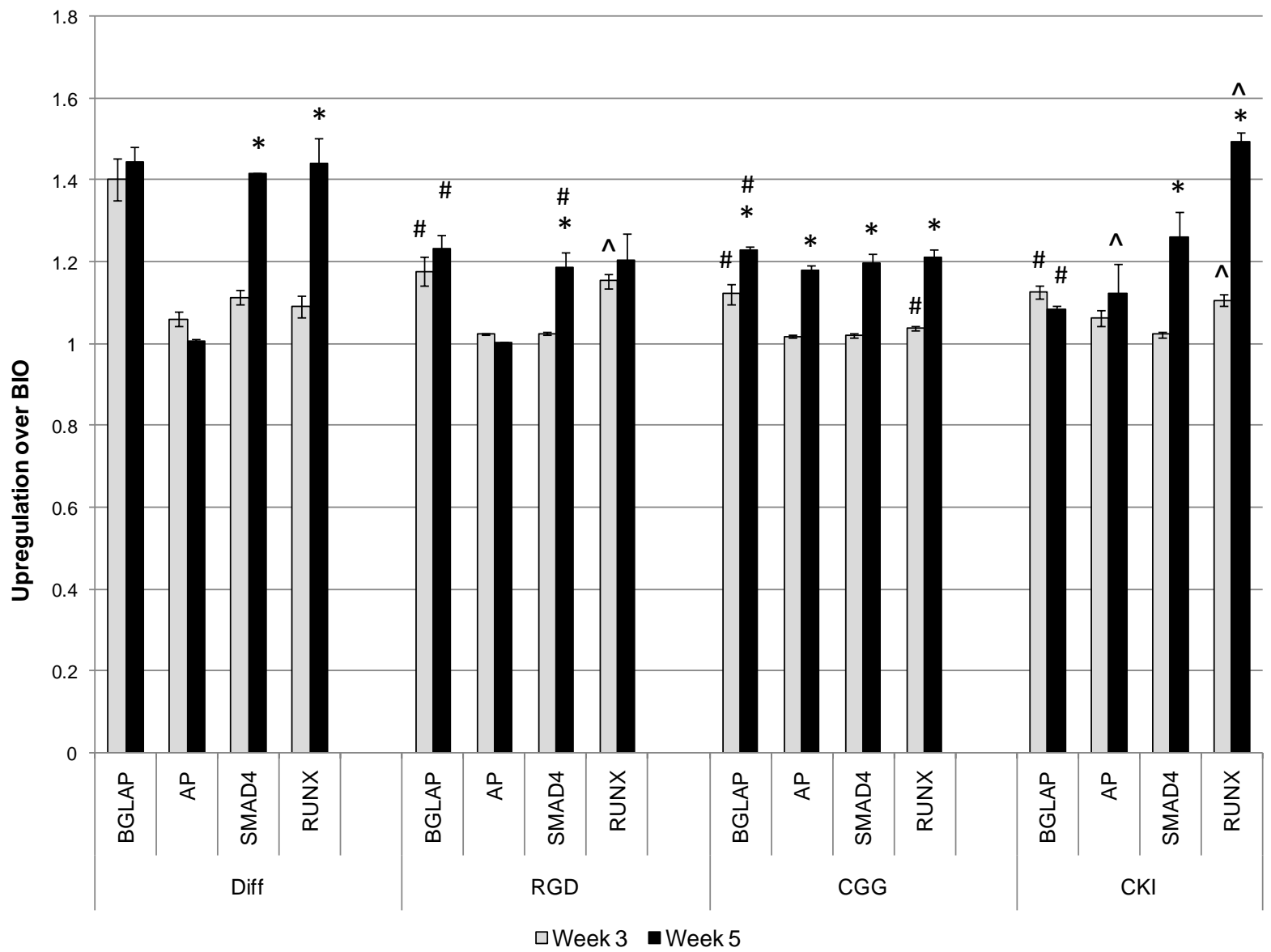

Figure 7. qRT-PCR analysis. Data was analyzed using the $\Delta \Delta \mathrm{Ct}$ method using GAPDH as a control gene and the BIO specimens (cells grown on bioactive glass in standard proliferation medium) as the reference sample. Data is presented as upregulation over the reference specimen, corrected for GAPDH expression. $*=$ Upregulation over 3 weeks, p $<0.01$, \# = Downregulation over Differentiation medium on Bioactive Glass, $\mathrm{p}<0.01, \wedge=$ Upregulation over Differentiation medium on Bioactive Glass, $\mathrm{p}<0.05$. 
Our data indicates that on bioactive glass samples that are treated with differentiation media, expression of AP peaks at Week 3; however, the CGG and CKI specimens appear to also undergo significant increases in AP expression, albeit a little later in the timeline. This could be indicative of either fresh enzyme production or a slight delay in differentiation over specimens that are treated with both soluble differentiation cues and an osteoproductive scaffold.

RunX is significantly upregulated in the Diff and RGD specimens at Week 3. RunX is involved with the control of osteocalcin expression; therefore, it is expected that these genes are consistently regulated. However, the CGG and CKI do not undergo any appreciable increase in RunX expression until Week 5, when all specimens demonstrate at least a $20 \%$ increase of RunX over the BIO specimens. In the CGG specimen, the expression levels of RunX rival those of the cells treated with differentiation media.

SMAD4 was not consistently upregulated in any specimen at Week 3. The Diff, RGD, CGG, and CKI specimens all exhibit a significant jump in SMAD4 mRNA expression by Week 5. The Diff specimens exhibit the most significant increase, as expected, but the cells grown on the CGG specimen are quite close in expression levels. Most notably, the SMAD4 increase in mRNA expression seems to peak after osteocalcin expression has peaked in these specimens. SMAD4, an important transcription factor in osteogenesis, is linked to osteocalcin expression via SMAD2, however, the exact timing and nature of this relationship is still not well understood, specifically as it relates to in vitro differentiation and BMP interactions in this signaling network.

The interactions of transcription factors and proteins involved in osteogenesis and bone growth are quite complex. The data presented here demonstrates that when cells are presented with solid-state cues (peptide-silanes) that mimic the active sites of key growth factors, the cells appear to respond in a similar way as they would if the cells are exposed to soluble differentiation factors in the form of small molecules. The differentiation timeline and expression profiles, while not perfectly in sync, are consistent across the different types of specimens treated, with the CGG specimen, containing three mixed peptide-silane cues, showing the most promise at potentially replacing media spiked with differentiation cues. This finding has broad implications across a wide variety of possible tissue engineering applications, from incorporating solid-state peptides into hydrogel "injectable” bone therapies, to coatings on permanent implants to facilitate attachment and site compatibility. This approach could surpass the potency of soluble growth factors in vitro, due to the extended and constant profile of the peptide-silane presentation. Future work should include a direct comparison of cells treated with soluble BMP-2 and BMP-9 with the cells grown on the solid-state networks.

\section{Conclusion}

This study examined the influence of bioactive peptides on the differentiation of MC3T3 cells grown on nanomacroporous bioactive glass. The approach described in this study represents a future enabling strategy in protein-free stem cell-based regenerative medicine. When compared to cells on non-modified bioactive glass that were treated with differentiation media, the cells on the peptide-silane treated samples underwent differentiation that was in line with cells treated with differentiation media, indicating that these solid-state cues were sufficient to enhance differentiation on bioactive glass in the absence of soluble signals. This is crucial in developing biomimetic bone scaffolds that do not contain the whole proteins or other difficult to control and possibly expensive molecular modifications. Ideally, these scaffolds would be placed in a location that provides the cells with necessary cues to regrow, and the peptides would enhance the re-growth of osteoblasts into the damaged area. To develop this study further, future research will include an analysis of the peptide-silane modified scaffolds in the presence of differentiation media and/or in the presence of the whole BMP-2, BMP-9 and fibronectin to determine if the multi-level approach of solid-state cues and soluble small molecules will enhance differentiation of the adherent osteoblasts.

\section{Acknowledgements}

We would like to thank the International Material Institute for New Functionality of Glass (NSF GRANT \# DMR-0844014) for summer undergraduate research funding for C. Przybylowski (2010). We also acknowledge the Lehigh University Faculty Innovation Grant for seed funding to assist with peptide development and analysis. In addition, we would like to thank Dr. Alfred Miller for providing the XPS spectra, Dr. JuttaMarzillier for qRTPCR assistance, and Drs. Himanshu Jain and Matthias Falk for useful discussion during the project. In addition, the qRT-PCR instrument was provided through an in-kind donation to Lehigh University from BD. 


\section{References}

[1] Hattar, S., Asselin, A., Greenspan, D., Oboeuf, M., Berdal, A. and Sautier, J.-M. (2005) Potential of Biomimetic Surfaces to Promote in Vitro Osteoblast-Like Cell Differentiation. Biomaterials, 26, 839-848. http://dx.doi.org/10.1016/j.biomaterials.2004.03.026

[2] Hench, L.L., Xynos, I.D., Edgar, A.J., Buttery, L.D.K., Polak, J.M., Zhong, J.-P., et al. (2002) Gene Activating Glasses. Journal of Inorganic Materials, 17, 897-909. http://www.jim.org.cn/EN/Y2002/V17/I5/897

[3] Xynos, I.D., Edgar, A.J., Buttery, L.D.K., Hench, L.L. and Polak, J.M. (2000) Ionic Products of Bioactive Glass Dissolution Increase Proliferation of Human Osteoblasts and Induce Insulin-Like Growth Factor II mRNA Expression and Protein Synthesis. Biochemical and Biophysical Research Communications, 276, 461-465. http://dx.doi.org/10.1006/bbrc.2000.3503

[4] Barboza, E.P., Caúla, A.L., de Oliveira Caúla, F., de Souza, R.O., Neto, L.G., Sorensen, R.G., et al. (2004) Effect of Recombinant Human Bone Morphogenetic Protein-2 in an Absorbable Collagen Sponge with Space-Providing Biomaterials on the Augmentation of Chronic Alveolar Ridge Defects. Journal of Periodontology, 75, 702-708. http://dx.doi.org/10.1902/jop.2004.75.5.702

[5] Bergeron, E., Marquis, M.E., Chrétien, I. and Faucheux, N. (2007) Differentiation of Preosteoblasts Using a Delivery System with BMPs and Bioactive Glass Microspheres. Journal of Materials Science: Materials in Medicine, 18, 255263. http://dx.doi.org/10.1007/s10856-006-0687-4

[6] Best, S.M., Porter, A.E., Thian, E.S. and Huang, J. (2008) Bioceramics: Past, Present and for the Future. Journal of the European Ceramic Society, 28, 1319-1327. http://dx.doi.org/10.1016/j.jeurceramsoc.2007.12.001

[7] Blaker, J.J., Gough, J.E., Maquet, V., Notingher, I. and Boccaccini, A.R. (2003) In Vitro Evaluation of Novel Bioactive Composites Based on Bioglass (R)-Filled Polylactide Foams for Bone Tissue Engineering Scaffolds. Journal of Biomedical Materials Research Part A, 67A, 1401-1411. http://dx.doi.org/10.1002/jbm.a.20055

[8] Blaker, J.J., Nazhat, S.N. and Boccaccini, A.R. (2004) Development and Characterisation of Silver-Doped Bioactive Glasscoated Sutures for Tissue Engineering and Wound Healing Applications. Biomaterials, 25, 1319-1329. http://dx.doi.org/10.1016/j.biomaterials.2003.08.007

[9] Chen, Q.Z.Z., Thompson, I.D. and Boccaccini, A.R. (2006) 45 S5 Bioglass ${ }^{\circledR}$ —Derived Glass—Ceramic Scaffolds for Bone Tissue Engineering. Biomaterials, 27, 2414-2425. http://dx.doi.org/10.1016/j.biomaterials.2005.11.025

[10] Hench, L.L. (2009) Genetic Design of Bioactive Glass. Journal of the European Ceramic Society, 29, 1257-1265. http://dx.doi.org/10.1016/j.jeurceramsoc.2008.08.002

[11] Hench, L.L. (1998) Bioceramics. Journal of the American Ceramic Society, 81, 1705-1728. http://dx.doi.org/10.1111/j.1151-2916.1998.tb02540.x

[12] Hench, L.L., Xynos, I.D. and Polak, J.M. (2004) Bioactive Glasses for in Situ Tissue Regeneration. Journal of Biomaterials Science-Polymer Edition, 15, 543-562. http://dx.doi.org/10.1163/156856204323005352

[13] Knabe, C., Stiller, M., Berger, G., Reif, D., Gildenhaar, R., Howlett, C.R. and Zreiqat, H. (2005) The Effect of Bioactive Glass Ceramics on the Expression of Bone-Related Genes and Proteins in Vitro. Clinical Oral Implants Research, 16, 119-127. http://dx.doi.org/10.1111/j.1600-0501.2004.01066.x

[14] Xynos, I.D., Hukkanen, M.V.J., Batten, J.J., Buttery, L.D., Hench, L.L. and Polak, J.M. (2000) Bioglass ${ }^{\circledR} 45 S 5$ Stimulates Osteoblast Turnover and Enhances Bone Formation in Vitro: Implications and Applications for Bone Tissue Engineering. Calcified Tissue International, 67, 321-329. http://dx.doi.org/10.1007/s002230001134

[15] Neo, M., Nakamura, T., Ohtsuki, C., Kokubo, T. and Yamamuro, T. (1993) Apatite Formation on 3 Kinds of Bioactive Material at an Early Stage in Vivo-A Comparative Study by Transmission Electron Microscopy. Journal of Biomedical Materials Research, 27, 999-1006. http://dx.doi.org/10.1002/jbm.820270805

[16] Maquet, V., Boccaccini, A.R., Pravata, L., Notingher, I. and Jérôme, R. (2003) Preparation, Characterization, and in Vitro Degradation of Bio-Resorbable and Bioactive Composites Based on Bioglass ${ }^{\circledR}$-Filled Polylactide Foams. Journal of Biomedical Materials Research Part A, 66A, 335-346. http://dx.doi.org/10.1002/jbm.a.10587

[17] Marques, A.C., Almeidaa, R.M., Thiema, A., Wang, S.J., Falk, M. and Jain, H. (2009) Sol-Gel-Derived Glass Scaffold with High Pore Interconnectivity and Enhanced Bioactivity. Journal of Materials Research, 24, 3495-3502. http://dx.doi.org/10.1557/jmr.2009.0440

[18] Garcia, A.J., Ducheyne, P. and Boettiger, D. (1998) Effect of Surface Reaction Stage on Fibronectin-Mediated Adhesion of Osteoblast-Like Cells to Bioactive Glass. Journal of Biomedical Materials Research, 40, 48-56. http://dx.doi.org/10.1002/(SICI)1097-4636(199804)40:1<48::AID-JBM6>3.0.CO;2-R

[19] Zhang, K., Wang, Y.B., Hillmyer, M.A. and Francis, L.F. (2004) Processing and Properties of Porous Poly(L-lactide)/ Bioactive Glass Composites. Biomaterials, 25, 2489-2500. http://dx.doi.org/10.1016/j.biomaterials.2003.09.033

[20] Arcos, D., Ragel, C.V. and Vallet-Regi, M. (2001) Bioactivity in Glass/PMMA Composites Used as Drug Delivery 
System. Biomaterials, 22, 701-708. http://dx.doi.org/10.1016/S0142-9612(00)00233-7

[21] Boccaccini, A.R. and Maquet, V. (2003) Bioresorbable and Bioactive Polymer/Bioglass ${ }^{\circledR}$ Composites with Tailored Pore Structure for Tissue Engineering Applications. Composites Science and Technology, 63, 2417-2429. http://dx.doi.org/10.1016/S0266-3538(03)00275-6

[22] Yao, J., Radina, S., Leboy, P.S. and Ducheyne, P. (2005) The Effect of Bioactive Glass Content on Synthesis and Bioactivity of Composite Poly (Lactic-Co-Glycolic Acid)/Bioactive Glass Substrate for Tissue Engineering. Biomaterials, 26, 1935-1943. http://dx.doi.org/10.1016/j.biomaterials.2004.06.027

[23] Kontonasaki, E., Sivropoulou, A., Papadopoulou, L., Garefis, P., Paraskevopoulos, K.M. and Koidis, P. (2006) Attachment and Proliferation of Human Periodontal Ligament Fibroblasts on Fibronectin-Coated Bioactive Glass Modified Ceramics. Bioceramics, 18, 727-730.

[24] Kaufmann, E., Ducheyne, P. and Shapiro, I.M. (2000) Evaluation of Osteoblast Response to Porous Bioactive Glass (45S5) Substrates by RT-PCR Analysis. Tissue Engineering, 6, 19-28. http://dx.doi.org/10.1089/107632700320856

[25] Lu, H.H., El-Amin, S.F., Scott, K.D. and Laurencin, C.T. (2003) Three-Dimensional, Bioactive, Biodegradable, PolymerBioactive Glass Composite Scaffolds with Improved Mechanical Properties Support Collagen Synthesis and Mineralization of Human Osteoblast-Like Cells in Vitro. Journal of Biomedical Materials Research Part A, 64A, 465-474. http://dx.doi.org/10.1002/jbm.a.10399

[26] Moura, J., Teixeira, L.N., Ravagnani, C., Peitl, O., Zanotto, E.D., Beloti, M.M., et al. (2007) In Vitro Osteogenesis on a Highly Bioactive Glass-Ceramic (Biosilicate ${ }^{\circledR}$ ). Journal of Biomedical Materials Research Part A, 82A, 545-557. http://dx.doi.org/10.1002/jbm.a.31165

[27] Oonishi, H., Kushitani, S., Yasukawa, E., Iwaki, H., Hench, L.L., Wilson, J., et al. (1997) Particulate Bioglass Compared with Hydroxyapatite as a Bone Graft Substitute. Clinical Orthopaedics and Related Research, 334, 316-325. http://www.ncbi.nlm.nih.gov/pubmed/9005929 http://dx.doi.org/10.1097/00003086-199701000-00041

[28] Sepulveda, P., Jones, J.R. and Hench, L.L. (2001) Characterization of Melt-Derived $45 S 5$ and Sol-Gel-Derived 58S Bioactive Glasses. Journal of Biomedical Materials Research, 58, 734-740. http://dx.doi.org/10.1002/jbm.10026

[29] Silver, I.A., Deas, J. and Erecinska, M. (2001) Interactions of Bioactive Glasses with Osteoblasts in Vitro: Effects of 45S5 Bioglass ${ }^{\circledR}$, and 58S and 77S Bioactive Glasses on Metabolism, Intracellular Ion Concentrations and Cell Viability. Biomaterials, 22, 175-185. http://dx.doi.org/10.1016/S0142-9612(00)00173-3

[30] Varanasi, V.G., Saizb, E., Loomer, P.M., Ancheta, B., Uritani, N., Ho, S.P., et al. (2009) Enhanced Osteocalcin Expression by Osteoblast-Like Cells (MC3T3-E1) Exposed to Bioactive Coating Glass $\left(\mathrm{SiO}_{2}-\mathrm{CaO}-\mathrm{P}_{2} \mathrm{O}_{5}-\mathrm{MgO}-\mathrm{K}_{2} \mathrm{O}-\mathrm{Na}_{2} \mathrm{O}\right.$ System) Ions. Acta Biomaterialia, 5, 3536-3547. http://dx.doi.org/10.1016/j.actbio.2009.05.035

[31] Verrier, S., Blakera, J.J., Maquet, V., Hench, L.L. and Boccaccini, A.R. (2004) PDLLA/Bioglass ${ }^{\circledR}$ Composites for Soft-Tissue and Hard-Tissue Engineering: An in Vitro Cell Biology Assessment. Biomaterials, 25, 3013-3021. http://dx.doi.org/10.1016/j.biomaterials.2003.09.081

[32] Vogel, M., Voigta, C., Gross, U.M. and Müller-Mai, C.M. (2001) In Vivo Comparison of Bioactive Glass Particles in Rabbits. Biomaterials, 22, 357-362. http://dx.doi.org/10.1016/S0142-9612(00)00191-5

[33] Yuan, H.P., de Bruijn, J.D., Zhang, X.D., van Blitterswijk, C.A. and de Groot, K. (2001) Bone Induction by Porous Glass Ceramic Made from Bioglass® ${ }^{\circledR}$ (45S5). Journal of Biomedical Materials Research, 58, 270- 276.

http://www.ncbi.nlm.nih.gov/pubmed/11319740 http://dx.doi.org/10.1002/1097-4636(2001)58:3<270::AID-JBM1016>3.0.CO;2-2

[34] Gao, T.J., Arob, H.T., Ylänen, H. and Vuorio, E. (2001) Silica-Based Bioactive Glasses Modulate Expression of Bone Morphogenetic Protein-2 mRNA in Saos-2 Osteoblasts in Vitro. Biomaterials, 22, 1475-1483. http://dx.doi.org/10.1016/S0142-9612(00)00288-X

[35] Kim, H.W., Lee, H.H. and Knowles, J.C. (2008) Nanofibrous Glass Tailored with Apatite-Fibronectin Interface for Bone Cell Stimulation. Journal of Nanoscience and Nanotechnology, 8, 3013-3019. http://www.ncbi.nlm.nih.gov/pubmed/18681040 http://dx.doi.org/10.1166/jnn.2008.106

[36] Leach, J.K., Kaiglerb, D., Wang, Z., Krebsbach, P.H. and Mooney, D.J. (2006) Coating of VEGF-Releasing Scaffolds with Bioactive Glass for Angiogenesis and Bone Regeneration. Biomaterials, 27, 3249-3255. http://dx.doi.org/10.1016/j.biomaterials.2006.01.033

[37] Bacakova, L., Filova, E., Kubies, D., Machova, L., Proks, V., Malinova, V., et al. (2007) Adhesion and Growth of Vascular Smooth Muscle Cells in Cultures on Bioactive RGD Peptide-Carrying Polylactides. Journal of Materials Science-Materials in Medicine, 18, 1317-1323. http://dx.doi.org/10.1007/s10856-006-0074-1

[38] De Giglio, E., Sabbatinib, L., Colucci, S. and Zambonin, G. (2000) Synthesis, Analytical Characterization, and Osteoblast Adhesion Properties on RGD-Grafted Polypyrrole Coatings on Titanium Substrates. Journal of Biomaterials Science, Polymer Edition, 11, 1073-1083. http://dx.doi.org/10.1163/156856200743580

[39] Morgan, A.W., Roskova, K.E., Lin-Gibson, S., Kaplan, D.L., Becker, M.L. and Simon Jr., C.G. (2008) Characteriza- 
tion and Optimization of RGD-Containing Silk Blends to Support Osteoblastic Differentiation. Biomaterials, 29, 25562563. http://dx.doi.org/10.1016/j.biomaterials.2008.02.007

[40] Itoh, D., Yoneda, S., Kuroda, S., Kondo, H., Umezawa, A., Ohya, K., et al. (2002) Enhancement of Osteogenesis on Hydroxyapatite Surface Coated with Synthetic Peptide (EEEEEEEPRGDT) in Vitro. Journal of Biomedical Materials Research, 62, 292-298. http://dx.doi.org/10.1002/jbm.10338

[41] Moursi, A.M., Damsky, C.H., Lull, J., Zimmerman, D., Doty, S.B., Aota, S., et al. (1996) Fibronectin Regulates Calvarialosteoblast Differentiation. Journal of Cell Science, 109, 1369-1380. http://www.ncbi.nlm.nih.gov/pubmed/8799825

[42] Yang, X.B., Roacha, H.I., Clarke, N.M.P., Howdle, S.M., Quirk, R., Shakesheff, K.M., et al. (2001) Human Osteoprogenitor Growth and Differentiation on Synthetic Biodegradable Structures after Surface Modification. Bone, 29, 523531. http://dx.doi.org/10.1016/S8756-3282(01)00617-2

[43] Massia, S.P. and Hubbell, J.A. (1991) An RGD Spacing of 440 nm Is Sufficient for Integrin Alpha V Beta 3-Mediated Fibroblast Spreading and $140 \mathrm{~nm}$ for Focal Contact and Stress Fiber Formation. Journal of Cell Biology, 114, 10891100. http://www.ncbi.nlm.nih.gov/pubmed/1714913 http://dx.doi.org/10.1083/jcb.114.5.1089

[44] Chen, D., Zhao, M. and Mundy, G.R. (2004) Bone Morphogenetic Proteins. Growth Factors, 22, $233-241$. http://www.ncbi.nlm.nih.gov/pubmed/15621726 http://dx.doi.org/10.1080/08977190412331279890

[45] Cheng, H.W., Jiang, W., Phillips, F.M., Haydon, R.C., Peng, Y., Zhou, L., et al. (2003) Osteogenic Activity of the Fourteen Types of Human Bone Morphogenetic Proteins (BMPs). Journal of Bone and Joint Surgery, American Volume, 85-A, 1544-1552. http://www.ncbi.nlm.nih.gov/pubmed/12925636

[46] Lee, K.S., Kim, H.J., Li, Q.L., Chi, X.Z., Ueta, C., Komori, T., et al. (2000) Runx2 Is a Common Target of Transforming Growth Factor Beta1 and Bone Morphogenetic Protein 2, and Cooperation between Runx2 and Smad5 Induces Osteoblast-Specific Gene Expression in the Pluripotentmesenchymal Precursor Cell Line C2C12. Molecular and Cellular Biology, 20, 8783- 8792.http://www.ncbi.nlm.nih.gov/pubmed/11073979 http://dx.doi.org/10.1128/MCB.20.23.8783-8792.2000

[47] Wozney, J.M. (1992) The Bone Morphogenetic Protein Family and Osteogenesis. Molecular Reproduction and Development, 32, 160-167. http://dx.doi.org/10.1002/mrd.1080320212

[48] Lee, J., Lee, J. and Murphy, W. (2010) Modular Peptides Promote Human Mesenchymal Stem Cell Differentiation on Biomaterial Surfaces. Acta Biomateriala, 6, 21-28. http://dx.doi.org/10.1016/j.actbio.2009.08.003

[49] Jedlicka, S.S., Rickus, J.L. and Zemyanov, D.Y. (2007) Surface Analysis by X-Ray Photoelectron Spectroscopy of Sol-Gel Silica Modified with Covalently Bound Peptides. Journal of Physical Chemistry B, 111, 11850-11857. http://dx.doi.org/10.1021/jp0744230

[50] Jedlicka, S.S., Little, K.M., Nivens, D.E., Zemlyanov, D. and Ri, J.L. (2007) Peptide Ormosils as Cellular Substrates. Journal of Materials Chemistry, 17, 5058-5067. http://dx.doi.org/10.1039/b705393b

[51] Vueva, Y., Gama, A., Teixeira, A.V., Almeida, R.M., Wang, S.J., Falk, M.M., et al. (2010) Monolithic Glass Scaffolds with Dual Porosity Prepared by Polymer-Induced Phase Separation and Sol-Gel. Journal of the American Ceramic Society, 93, 1945-1949. http://dx.doi.org/10.1111/j.1551-2916.2010.03697.x

[52] Wang, S., Falk, M.M., Rashad, A., Saad, M.M., Marques, A.C., Almeida, R.M., et al. (2011) Evaluation of 3D NanoMacro Porous Bioactive Glass Scaffold for Hard Tissue Engineering. Journal of Materials Science-Materials in Medicine, 22, 1195-1203. http://www.ncbi.nlm.nih.gov/pubmed/21445655 http://dx.doi.org/10.1007/s10856-011-4297-4

[53] Wang, S.J. and Jain, H. (2010) High Surface Area Nano-Macroporous Bioactive Glass Scaffold for Hard Tissue Engineering. Journal of the American Ceramic Society, 93, 3002-3005. http://dx.doi.org/10.1111/j.1551-2916.2010.03970.x

[54] Hamid, R., Rotshteyn, Y., Rabadi, L., Parikh, R. and Bullock, P. (2004) Comparison of Alamar Blue and MTT Assays for High Through-Put Screening. Toxicology in Vitro, 18, 703-710. http://dx.doi.org/10.1016/j.tiv.2004.03.012

[55] Benesch, J., Mano, J.F. and Reis, R.L. (2008) Proteins and Their Peptide Motifs in Acellular Apatite Mineralization of Scaffolds for Tissue Engineering. Tissue Engineering Part B-Reviews, 14, 433-445. http://dx.doi.org/10.1089/ten.teb.2008.0121

[56] Takeuchi, A., Ohtsuki, C., Kamitakahara, M., Ogata, S.-I., Miyazaki, T. and Tanihara, M. (2008) Biomimetic Deposition of Hydroxyapatite on a Synthetic Polypeptide with Beta Sheet Structure in a Solution Mimicking Body Fluid. Journal of Materials Science: Materials in Medicine, 19, 387-393. http://www.ncbi.nlm.nih.gov/pubmed/17607510 http://dx.doi.org/10.1007/s10856-007-3179-2

[57] Lian, J.B., Javed, A., Zaidi, S.K., Lengner, C., Montecino, M., van Wijnen, A.J., et al. (2004) Regulatory Controls for Osteoblast Growth and Differentiation: Role of Runx/Cbfa/AML Factors. Critical Reviews in Eukaryotic Gene Expression, 14, 1-41. http://www.ncbi.nlm.nih.gov/pubmed/15104525 
[58] Ducy, P., Geoffroy, V. and Karsenty, G. (1996) Study of Osteoblast-Specific Expression of one Mouse Osteocalcin Gene: Characterization of the Factor Binding to OSE2. Connective Tissue Research, 35, 7-14. http://www.ncbi.nlm.nih.gov/pubmed/9084638 http://dx.doi.org/10.3109/03008209609029169

[59] Gaur, T., Lengner, C.J., Hovhannisyan, H., Bhat, R.A., Bodine, P.V.N., Komm, B.S., et al. (2005) Canonical WNT Signaling Promotes Osteogenesis by Directly Stimulating Runx2 Gene Expression. Journal of Biological Chemistry, 280, 33132-33140. http://www.ncbi.nlm.nih.gov/pubmed/16043491 http://dx.doi.org/10.1074/jbc.m500608200

[60] Hanada, K., Dennis, J.E. and Caplan, A.I. (1997) Stimulatory Effects of Basic Fibroblast Growth Factor and Bone Morphogenetic Protein-2 on Osteogenic Differentiation of Rat Bone Marrow-Derived Mesenchymal Stem Cells. Journal of Bone and Mineral Research, 12, 1606-1614. http://www.ncbi.nlm.nih.gov/pubmed/9333121 http://dx.doi.org/10.1359/jbmr.1997.12.10.1606

[61] Banerjee, C., Javed, A., Choi, J.Y., Green, J., Rosen, V., van Wijnen, A.J., et al. (2001) Differential Regulation of the Two Principal Runx2/Cbfa1 N-Terminal Isoforms in Response to Bone Morphogenetic Protein-2 during Development of the Osteoblast Phenotype. Endocrinology, 142, 4026-4039. http://www.ncbi.nlm.nih.gov/pubmed/11517182 http://dx.doi.org/10.1210/endo.142.9.8367

[62] Ito, Y. and Miyazono, K. (2003) RUNX Transcription Factors as Key Targets of TGF-Beta Superfamily Signaling. Current Opinion in Genetics \& Development, 13, 43-47. http://dx.doi.org/10.1016/S0959-437X(03)00007-8

[63] Hoffmann, A., Preobrazhenska, O., Wodarczyk, C., Medler, Y., Winkel, A., Shahab, S., et al. (2005) Transforming Growth Factor-Beta-Activated Kinase-1 (TAK1), a MAP3K, Interacts with Smad Proteins and Interferes with Osteogenesis in Murinemesenchymal Progenitors. Journal of Biological Chemistry, 280, 27271-27283. http://dx.doi.org/10.1074/jbc.M503368200

[64] Li, J., Tsuji, K., Komori, T., Miyazono, K., Wrana, J.L., Ito, Y., et al. (1998) Smad2 Overexpression Enhances Smad4 Gene Expression and Suppresses CBFA1 Gene Expression in Osteoblasticosteosarcoma ROS17/2.8 Cells and Primary Rat Calvaria Cells. Journal of Biological Chemistry, 273, 31009-31015. http://dx.doi.org/10.1074/jbc.273.47.31009

[65] Stein, G.S. and Lian, J.B. (1993) Molecular Mechanisms Mediating Proliferation Differentiation Interrelationships during Progressive Development of the Osteoblast Phenotype. Endocrine Reviews, 14, 424-442. http://www.ncbi.nlm.nih.gov/pubmed/8223340 http://dx.doi.org/10.1210/edrv-14-4-424

[66] Stein, G.S. and Lian, J.B. (1993) Cellular and Molecular Biology of Bone. Academic Press, San Diego. 